\title{
Remote Sensing Imagery and GIS for Monitoring the Pyroclastic Material of Mount Sinabung
}

\author{
Cahyadi Setiawan*, Muzani, Warnadi, F.R. A'Rachman, Qismaraga and Ermalia \\ Department of Geographic Education, Faculty of Social Science, Universitas Negeri Jakarta, Jakarta, \\ Indonesia \\ *) Corresponding Author (e-mail: cahyadi-setiawan@unj.ac.id)
}

Received: 15 November 2019 / Accepted: 13 January 2020 / Published: 06 February 2020

\begin{abstract}
The purpose of this study is to determine the extent of changes in land cover around the Mount Sinabung area after the 2009-2019 eruption by monitoring through remote sensing imagery and GIS. The method used in the research is descriptive quantitative. Data collection was made using document study techniques by collecting Landsat images, which are among the most widely used satellite remote sensing data, with their spectral, spatial and temporal resolution making them useful input for mapping and planning projects (Sadidy et al. 1981). Changes in land cover that occurred around the Mount Sinabung area were dominated by pyroclastic material following the eruption. In addition, changes also occurred due to the abandonment of potential land; for example, local residents working in the plantation sector were forced to leave, so the land was eventually taken over by shrubs. The direction of the dominant pyroclastic material slides was towards the east-south and southeast of Mount Sinabung, areas dominated by the plantation sector. The impacts of the eruption of the mountain were direct and indirect. In 2010, total land cover changes due to pyroclastic material affected an area of $26.27 \mathrm{Ha}$; in 2014 475.82 Ha were affected; $1339.75 \mathrm{Ha}$ in 2017; and 1196.11 Ha in 2019.
\end{abstract}

Keywords: Remote Sensing, Land Cover, Pyroclastic Material, Landsat

\begin{abstract}
Abstrak. Tujuan dari penelitian ini adalah untuk menentukan tingkat perubahan tutupan lahan di sekitar kawasan Gunung Sinabung setelah letusan 2009-2019 dengan memantau melalui penginderaan jauh dan GIS. Metode yang digunakan dalam penelitian ini adalah deskriptif kuantitatif. Teknik pengumpulan data menggunakan teknik studi dokumen dengan mengumpulkan Citra Landsat yang merupakan data penginderaan jauh satelit yang banyak digunakan dengan resolusi spektral, spasial dan temporal menjadikannya berguna untuk pemetaan dan perencanaan proyek (Sadidy et al. 1981). Perubahan tutupan lahan yang terjadi di sekitar kawasan Gunung Sinabung didominasi oleh material piroklastik akibat erupsi. Perubahan tutupan lahan juga terjadi karena ditinggalkannya lahan potensial, seperti penduduk lokal yang bekerja di sektor perkebunan terpaksa meninggalkannya sehingga berubah menjadi semak belukar. Arah material piroklastik dominan ke arah timur-selatan dan tenggara Gunung Sinabung yang didominasi oleh sektor perkebunan. Dampak dari letusan Gunung Sinabung ada secara langsung dan tidak langsung. Total perubahan tutupan lahan karena tutupan bahan piroklastik pada tahun 2010 adalah seluas $26.27 \mathrm{Ha}$, pada tahun 2014 adalah $475.82 \mathrm{Ha}, 2017$ adalah 1339.75 Ha, dan 2019 adalah 1196.11 Ha.
\end{abstract}

Kata kunci: Penginderaan Jauh, Tutupan Lahan, Material Piroklastik, Landsat

\section{Introduction}

Indonesia has the most active volcanoes in the world, with around $30 \%$ located in the country. The tectonic setting of Indonesia, which is generated by the interactions between the Eurasia plate in the north, the India-Australian plate in the south, and the Pacific plate in the east, is the reason for 
the elevated volcanic activity (Kusumayudha et al., 2018). The characteristics of volcanoes are influenced by their magmatic properties, especially the volatile and silica $\left(\mathrm{SiO}_{2}\right)$ content. These will result in gas pressure and viscosity of the magma, defining the volcanic eruption type. Sinabung is one of most active volcanoes, and is located in Karo District, North Sumatra.

The volcano, located specifically in Tanah Karo, is one of the 30 volcanoes situated above the Sumatran fault and is the closest active volcano to the ancient "Super Mountain". Mount Sinabung is in the Karo Highlands, Karo District, North Sumatra Province, Indonesia. The geographical position of the peak of Mount Sinabung is latitude $3^{\circ} 10^{\prime}$ north and longitude $98^{\circ} 23.5^{\prime}$ east. The height of the mountain is $2460 \mathrm{~m}$ above sea level, and its volcano type is a stratovolcano (Ministry of Energy and Natural Resources of the Republic of Indonesia, 2013). Sinabung, which has been active since 2010, having been dormant for 400 years, has a better position above the Sumatran fault than its parent; this fault is one of the two most active ones in the world.

Sinabung became active after the earthquake, accompanied by a devastating tsunami, that shook Aceh on December 26, 2004. The resulting tsunami reached Hawaii and beaches around Sumatra and Java, with the height of the waving reached $40 \mathrm{~m}$. The impact of the Indo-Australian and Eurasian plates, where the volcano continues to be activated. The earthquake that caused the Aceh tsunami occurred due to plate activity at a depth of 10 $\mathrm{km}, 160 \mathrm{~km}$ from the west coast of Aceh, and it has emerged that shallow volcanic earthquakes around a depth of $3 \mathrm{~km}$ below Sinabung were recorded dozens of times a day, accompanied by several tectonic earthquakes at a depth of 10 $\mathrm{km}$. This was followed by the Nias earthquakes in March 2005 and July 2006, and the Padang earthquake in March 2007, which recurred in September 2009 , followed by a Nias earthquake once again in October 2009. A year later, on August 29, 2010, eruptive activity of Mount Sinabung reawake after more than 400 years of dormancy (Iguchi et al., 2011).
The Sinabung volcano is located in a weak zone in the east of the Sumatra fault segment. Its eruptions produce volcanic rock deposits that can be grouped into 25 units (Center of Volcanology and Geologic Disaster Mitigation (CVGDM), 2015). The volcano occurs to the northwest of Old Toba basin. There is a strike-slip fault dissecting almost all the rock formation along the west edge of the basin. Besides the occurrence of this strike-slip fault, there is a normal fault found at Kawar Lake. In the study area, the geological structure pattern shows a southwest-northeast axis, as well as the crater structure of the volcano, which is at a northwest-southeast orientation (Geologic Agency of Indonesia, 2011). Sinabung volcano is its "child" because the burst hole at its peak continues to multiply and grow; it can be said that the impetus of magma would be increasingly attracted to focus on this exit point. Data on the occurrence of Sinabung eruption disasters are shown in Table 1.

Table 1. Data on the Genesis of Mount Sinabung Eruptions

\begin{tabular}{|c|c|c|}
\hline No. & Date of Genesis & $\begin{array}{c}\text { Height of } \\
\text { Volcanic Ash } \\
\text { Column (m) }\end{array}$ \\
\hline \multirow[t]{2}{*}{1} & 27 August 2010 & \multirow{2}{*}{2900} \\
\hline & 29 August 2010 & \\
\hline \multirow[t]{6}{*}{2} & 17 September 2013 & \multirow{4}{*}{5000} \\
\hline & 18 September 2013 & \\
\hline & 19 September 2013 & \\
\hline & 3 November 2013 & \\
\hline & 20 November 2013 & \multirow[t]{2}{*}{8000} \\
\hline & 23 November 2013 & \\
\hline 3 & 3 January 2014 & 4000 \\
\hline \multirow[t]{2}{*}{4} & 2 August 2017 & 4200 \\
\hline & 27 December 2017 & 4600 \\
\hline 5 & 19 February 2018 & 5000 \\
\hline
\end{tabular}

Sinabung volcano had been inactive for around 400 years (Kusumayudha, 2013; Kusumayudha etal.,2018).Surprising, it erupted on 27 August 2010, and again in November 2013, May to June 2015, May 2016, February to April 2018, and June 6, 2019 (Kusumayudha et 
al., 2018). The relatively long eruption period of Sinabung had an impact on the lives and activities of the population around the volcano; they used to feel safe, but now felt as if they were in vulnerable place. The communities living in the active volcano areas were threatened by the continued risk of volcanic eruption. This could happen at any time and had the potential to destroy everything located in the surrounding areas (Wardhani and Sartohadi, 2017).

The series of eruptions have led to the number of refugees reaching 26,174 $(8,161$ households), scattered in 39 refugee points (Bachri et al., 2019). The direct impact of the eruptions is the pyroclastic materials, such as bombs, gravel, sand and volcanic ash (Primulyana et al., 2018)2. Field observations have shown characteristics of ash Sinabung deposits content dust to fine sand. In addition, eruption material classified as bombs (rocks measuring $>6 \mathrm{~cm})$ and gravel $(2 \mathrm{~mm}$ to $6.4 \mathrm{~cm})$ was also issued. The thickness of the deposition of new materials varies (Supartoyo et al., 2014). Sinabung pyroclastic material influences the surrounding land cover. The material sources describe the origin of intrusion rocks and volcanic rocks that made-up (Hartono et al., 2017; Wright et al., 2018)Indonesia have been ongoing since 2013. Since that time, the character of eruptions has changed, from phreatic to phreatomagmatic to magmatic explosive eruptions, and from production of a lava dome that collapsed to a subsequent thick lava flow that slowly ceased to be active, and later, to a new lava dome. As the eruption progressed, event trees were constructed to forecast eruptive behavior six times, with forecast windows that ranged from 2. weeks to 1 . year: November 7-10, December 12-14, and December 27, 2013; and January 9-10, May 13, and October 7, 2014. These event trees were successful in helping to frame the forecast scenarios, to collate current monitoring information, and to document outstanding questions and unknowns. The highest probability forecasts closely matched outcomes of eruption size (including extrusion of the first dome. Pyroclastic rocks have not undergone the process of transport in a medium, so they freeze in the air at the time of the eruption of the active volcano. The method of pyroclastic rock formation, which is from volcanic eruptions, removes magma from the earth due to the enormous energy. There are three types of pyroclastic rock deposition mechanisms, namely: 1) fall deposits, which are pyroclastic deposits formed by the fall of fine minerals carried by the wind; 2) flow deposits, which are pyroclastic deposits transported by water media, where mixing of all sizes of granules occurs; and 3) surge deposits, which are a combination of pyroclastic deposits formed by fall and flow.

Volcanic activity has often affected human life, both on the large and small scale. For example, the 2010 eruption caused severe economic damage on a continental scale due to its serious effect on air traffic. On a local scale, ash fall and lava flow emission can cause harm and disruption (Amici et al., 2013). Understanding the behaviour of active volcanoes and evaluating the associated hazards are scientific challenges for protection of people that living in active volcano areas (Clarisse et al., 2010; Setiawan, 2019).

One of the biggest problems when monitoring active volcanoes arises from the difficulty in accessing summit areas because of logistical problems and volcanic hazard. In the last twenty years, the use of remote sensing techniques has become more and more popular and effective in measuring certain volcano parameters. In order to obtain both an overall view of the behaviour of an active volcano or more precise local information, multiple scale approaches are used (Amici et al., 2013). Remote sensing is the science and art of obtaining information about an object, phenomenon or region through the analysis of data collected with a device without direct contact with the object, area or event studied (Somantri, 2008). Remote sensing plays a vital role in analysing objects without having to visit the target area. It provides convenience and reduces the risk from the object studied. 
The objective of this study is to assess the eruption characteristics of Sinabung volcano and to monitor the direction, pattern and movement of its pyroclastic material with remote sensing and GIS. The methodology is expected to be able to increase public and government awareness in order to reduce future disaster risk and the number of disaster victims. Several different approaches to the evaluation of volcano hazards can be found in the current literature. Kadavi et al. (2017) analysed the evaluation of volcano hazard, especially pyroclastic deposits, using land classification with Landsat imagery data and the artificial neural network approach. They employed land classification with satellite imagery using an artificial neural network method to analyse the areas affected by eruptions of Mounts Sinabung and Merapi. Lee et al. (2015) showed that the most frequently used neural network method is the backpropagation learning algorithm, an algorithm of a multilayered neural network that consists of an input layer, hidden layers and an output layer in Mount Sinabung.

\section{Research Method}

This study location was Sinabung volcano, Karo District, North Sumatra (Figure 1). The research used five Landsat satellite images before and after the eruptions of 2009 and 2019 (Table 2), which were downloaded and used to detect changes in land cover. The types of land cover analysed after the eruption were forest, built-up areas, bare land, pyroclastic material, farms, fields and shrubs. The satellite images were sorted and classified for analysis and interpretation. Landsat images are among the most widely used satellite remote sensing data and their spectral, spatial and temporal resolution make them useful input for mapping and planning projects (Sadidy et al., 1981).

The reports compiled satellite imagery obtained through USGS by downloading Landsat 5 (MSS) satellite imagery for 2009 (Figure 3), Landsat 5 (MSS) satellite imagery for 2010 (Figure 4), Landsat 8 (OLI) satellite imagery for 2014 (Figure 5), Landsat 8 (OLI) satellite imagery for 2017 (Figure 6), and Landsat 8 (OLI) satellite imagery for 2019 (Figure 7).

Table 2. Data Sources

\begin{tabular}{cccc}
\hline No. & Data & Source & Information \\
\hline 1 & Landsat 5 (MSS) Satellite Imagery for 2009 & earthexplorer.usgs.gov & Volcanic Ash Column in 2009 \\
2 & Landsat 5 (MSS) Satellite Imagery for 2010 & earthexplorer.usgs.gov & Pyroclastic Material in 2010 \\
3 & Landsat 8 (OLI) Satellite Imagery for 2014 & earthexplorer.usgs.gov & Pyroclastic Material in 2014 \\
4 & Landsat 8 (OLI) Satellite Imagery for 2017 & earthexplorer.usgs.gov & Pyroclastic Material in 2017 \\
5 & Landsat 8 (OLI) Satellite Imagery for 2019 & earthexplorer.usgs.gov & Pyroclastic Material in 2019 \\
\hline
\end{tabular}

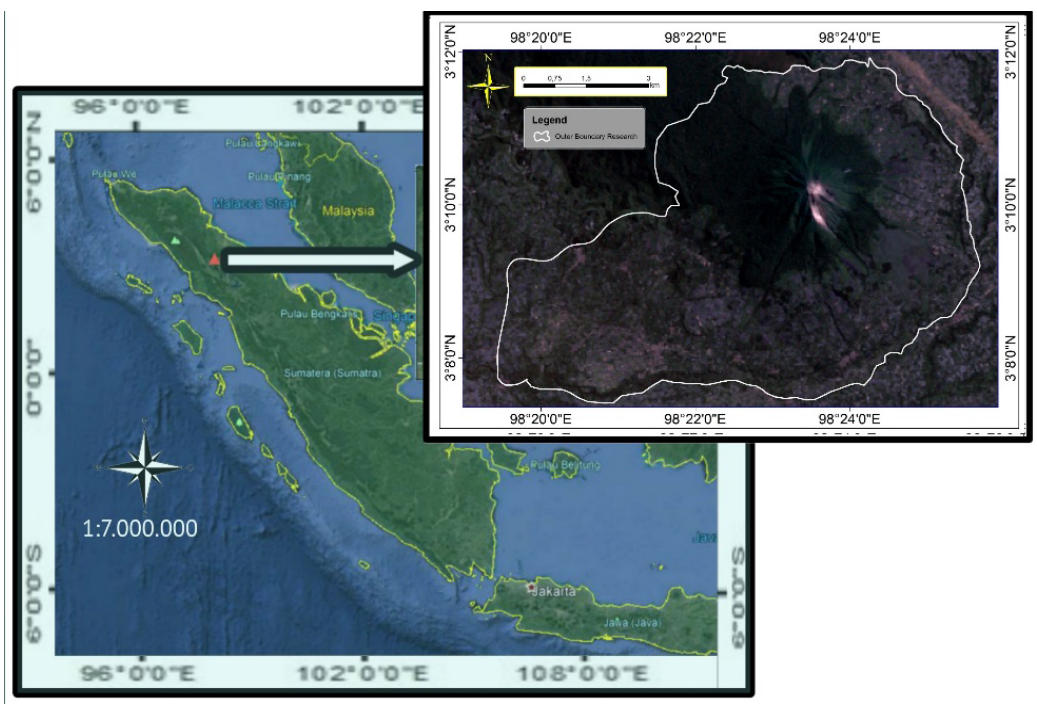

Figure 1. Research Location Map. 


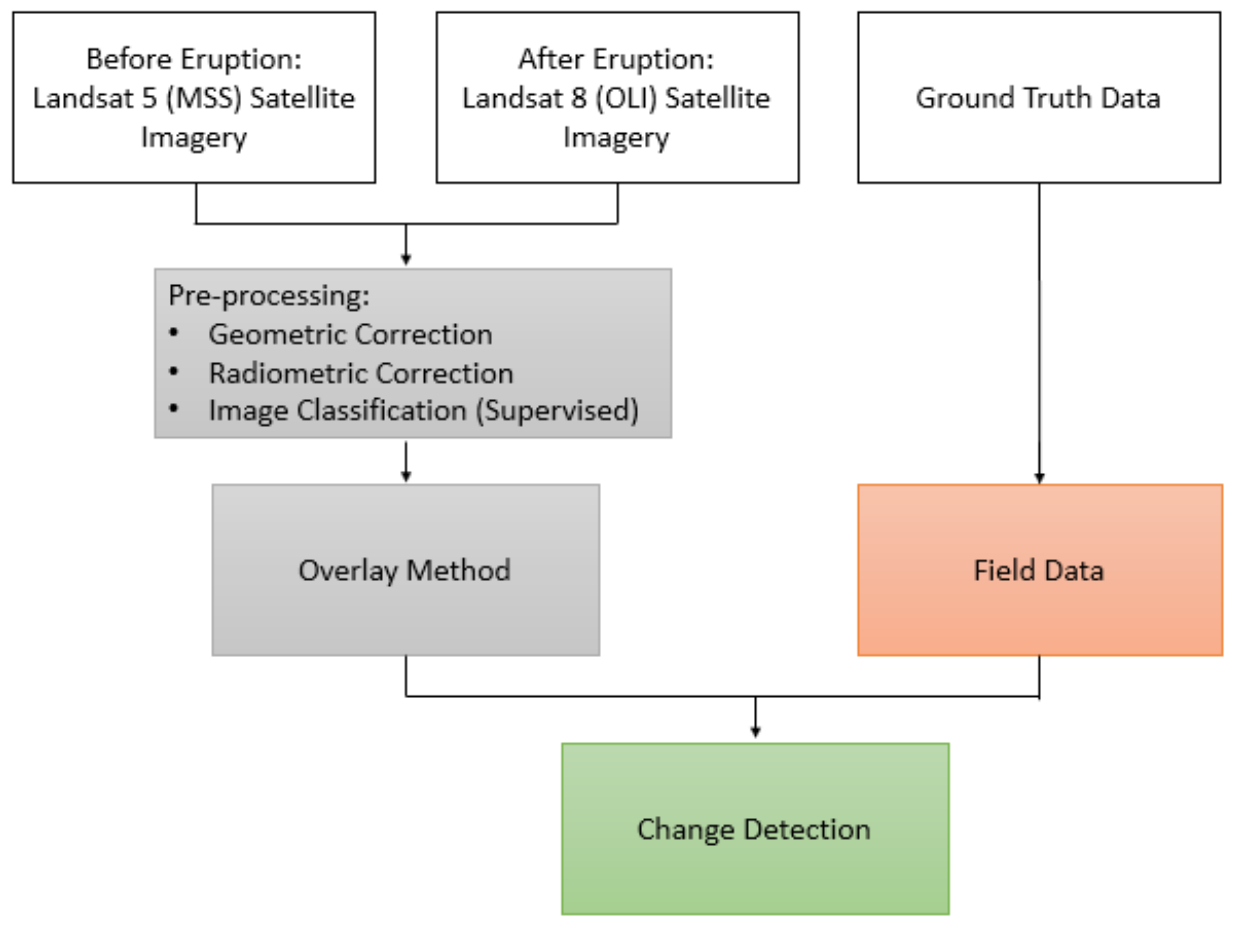

Figure 2. Study workflow.

As shown in Figure 2, we used two satellite images, one before and one after, the eruptions of 2010 and 2019. The research employed two kinds of analysis, digital and visual, also known as a mixed review, for the Landsat 5 and Landsat 8 imagery using visual analysis (digitizing). The digital analysis was performed using the ENVI 5.3 application and used in a guided manner with the Maximum Likelihood Classification tools. These perform maximum likelihood classification on a set of raster bands and create a classified raster as output. The tools consider both the variances and covariances of the class signatures when assigning each cell to one of the classes represented in the signature file. After the digital classification data had appeared, the researcher continued with visual analysis by digitization. Visual examination of the ArcGIS Satellite and Google Earth imagery was made by directly scanning and providing land cover classes. Satellite images of the research area were downloaded from USGS for 2009, 2010, 2014, 2017 and 2019.

The method used in the research is descriptivequantitative. The quantitativeanalysis technique was used for describing the data input, the percentage of respondent answers, and nonparametric correlation analysis (Setiawan et al., 2017). The data collection technique applied in this study was analytical, using primary and secondary data. It began with assessment of the existing data, in the form of written documents, drawings, paper works and various electronics data (Kusumayudha et al., 2018; Raynolds et al., 2015). The reports compiled are satellite imagery obtained through USGS. Therefore, the type of data used was secondary.

\section{Results and Discussion}

\subsection{The Dynamic of Land Cover}

The dynamics of the changes in land cover around the Mount Sinabung area already happen (Yulianto et al., 2016; Yusnikusumah, 2016). Forest land cover tends to decrease from 2010-2017 but increases in 2019; this happens because the location of the forest is around Mount Sinabung so there are significant changes. From 2017 to 2019, the forest area increased, which was perhaps because its vulnerability to the 2017 and 2019 eruptions of Mount Sinabung was not so great (Table 3 and Table 4). 
Table 3. Comparison of Land Cover Area between 2009 and 2019

\begin{tabular}{|c|c|c|c|c|c|c|}
\hline \multirow{2}{*}{ No } & \multirow{2}{*}{ Land Cover } & \multicolumn{5}{|c|}{ Area (Ha) } \\
\hline & & 2009 & 2010 & 2014 & 2017 & 2019 \\
\hline 1 & Forest & $1560.24=$ & $1560,24>$ & $1436.16>$ & 1148.43 & 1360.36 \\
\hline 2 & Built-up Areas & $82.5^{\circ}$ & 82.5 ス & 89.2 ス & $100.02-$ & 100.02 \\
\hline 3 & Bare Land & 599.30 \ & $57 ., 03$ ע & 477.32 ע & 446.45 \ & 423.3 \\
\hline 4 & $\begin{array}{l}\text { Pyroclastic } \\
\text { Material }\end{array}$ & $0 \nearrow$ & 26.27 入 & ل & $1339.75 \searrow$ & 1196.11 \\
\hline 5 & Farms & 3053.51 & 3053.51 ע & 2810.18 ע & 2729.36 ע & 2660.77 \\
\hline 6 & Fields & $374.05^{\prime}$ & ل & $385.4^{\circ}$ & $263.13 \times$ & 257.36 \\
\hline 7 & Shrubs & 736.46 & 736.46 \ & 731.98 \ & ד & 408.14 \\
\hline & Total & 6406.06 & 6406.06 & 6406.06 & 6406.06 & 6406.06 \\
\hline
\end{tabular}

$$
\begin{array}{ll} 
& \text { Information: } \\
& \text { : does not change } \\
& \text { : increases } \\
& \text { : decreases }
\end{array}
$$

\begin{tabular}{|c|c|c|c|c|c|c|c|c|c|c|}
\hline \multirow{2}{*}{ No, } & \multirow{2}{*}{ Land Cover Class } & \multicolumn{2}{|c|}{$\begin{array}{l}\text { Coverage Land } \\
\text { Cover Area (Ha) }\end{array}$} & \multicolumn{3}{|c|}{$\begin{array}{c}\text { Coverage Area Pyroclastic } \\
\text { (Ha) }\end{array}$} & \multicolumn{4}{|c|}{ Percentage \% } \\
\hline & & 2010 & 2014 & 2017 & 2010 & 2014 & 2017 & 2010 & 2014 & 2017 \\
\hline 1 & Forest & 0 & 1436.16 & 1148.43 & 43.94 & 43.94 & 21.88 & 0 & 3.05 & 1.9 \\
\hline 2 & Built-up Areas & 0 & 0 & 100.02 & 0 & 0 & 7.76 & 0 & 0 & 7.75 \\
\hline 3 & Pyroclastic Material & 0 & 0 & 0 & 16.77 & 0 & 0 & 0 & 0 & 0 \\
\hline 4 & Bare Land & 0 & 477.32 & 446.45 & 155.58 & 155.58 & 225.25 & 0 & 32.60 & 50.45 \\
\hline 5 & Farms & 0 & 2810.18 & 2729.36 & 253.53 & 253.53 & 459.62 & 0 & 9.02 & 16.8 \\
\hline 6 & Fields & 0 & 731.98 & 378.92 & 6 & 6 & 185.7 & 0 & 0.82 & 49 \\
\hline
\end{tabular}

Table 4. Percentage Comparison of 2010, 2014 and 2017 Land Cover and Pyroclastic Material

Source: Data Analysis (2019)

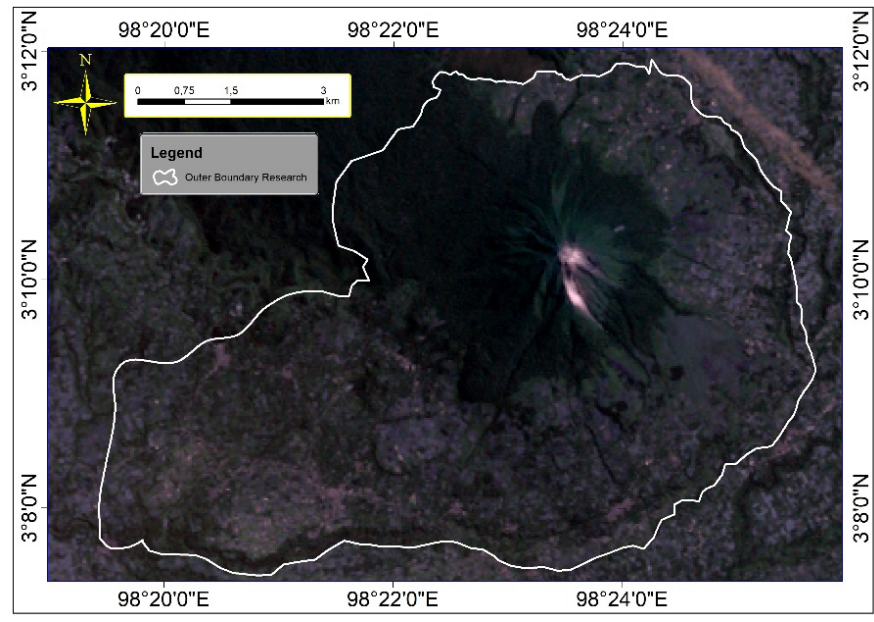

Figure 3. Landsat 5 (MSS) Satellite Imagery of 2009. 
The total land cover changes due to pyroclastic material in 2010 was an area of 26.27 $\mathrm{Ha}$; in 2014 it was $475.82 \mathrm{Ha}$, in $20171339.75 \mathrm{Ha}$ and in $20191196.11 \mathrm{Ha}$.

\subsection{Discussion}

At the beginning of the eruption around the end of 2009 (Figure 3) up to August 2010 (Figure 4), the activity of Sinabung volcano, which has been inactive for a long time (more than 400 years) shocked the local residents, even though the height of the volcanic ash column was only around $2900 \mathrm{~m}$. After the 2010 eruption, the volcano returned to a dormant stage for two years before erupting again in mid-September 2013, with the height of the volcanic ash column nearly doubling that of the 2010 explosion, at around $5000 \mathrm{~m}$ (Hendrasto et al., 2012). The use of high-resolution imagery produced more in-depth analysis in monitoring the direction, pattern, and movement of the Sinabung pyroclastic material (Kadavi et al., 2017).

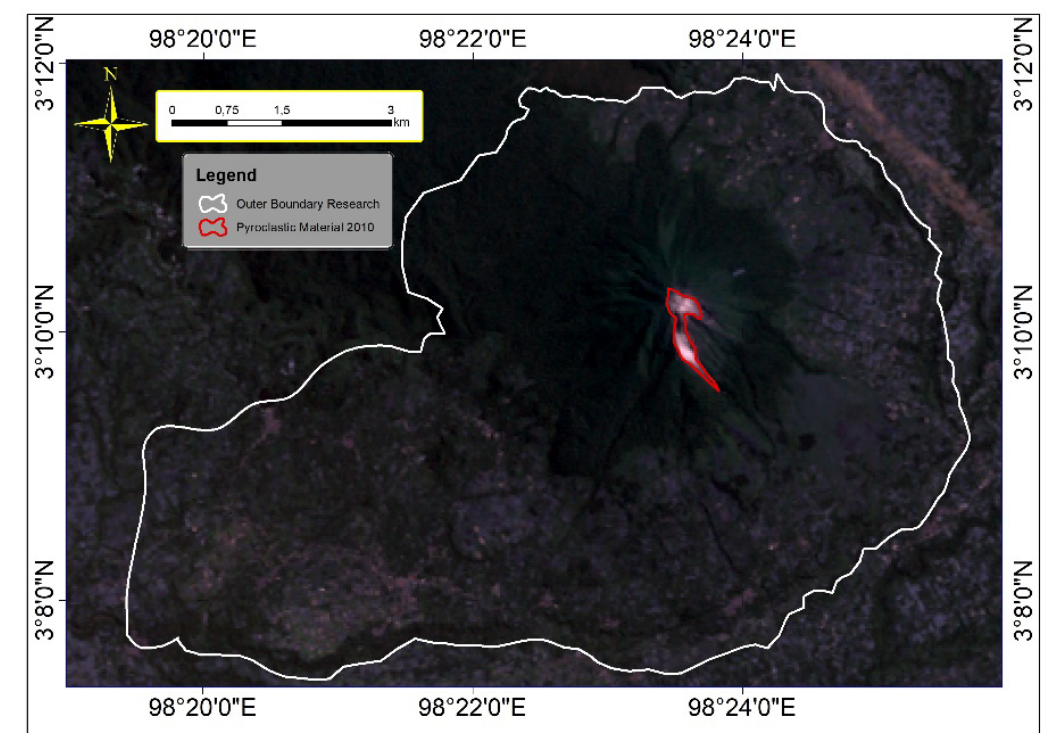

Figure 4. Landsat 5 (MSS) Satellite Imagery 2010.



Figure 5. Landsat 8 (OLI) Satellite Imagery 2014. 


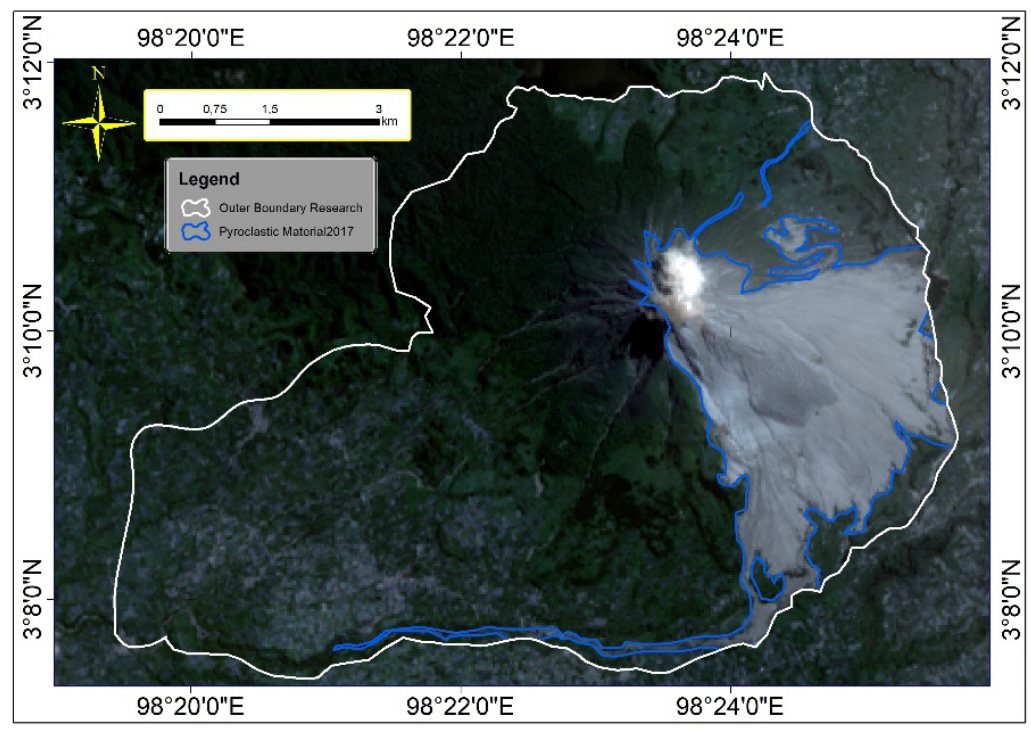

Figure 6. Landsat 8 (OLI) Satellite Imagery of 2017.

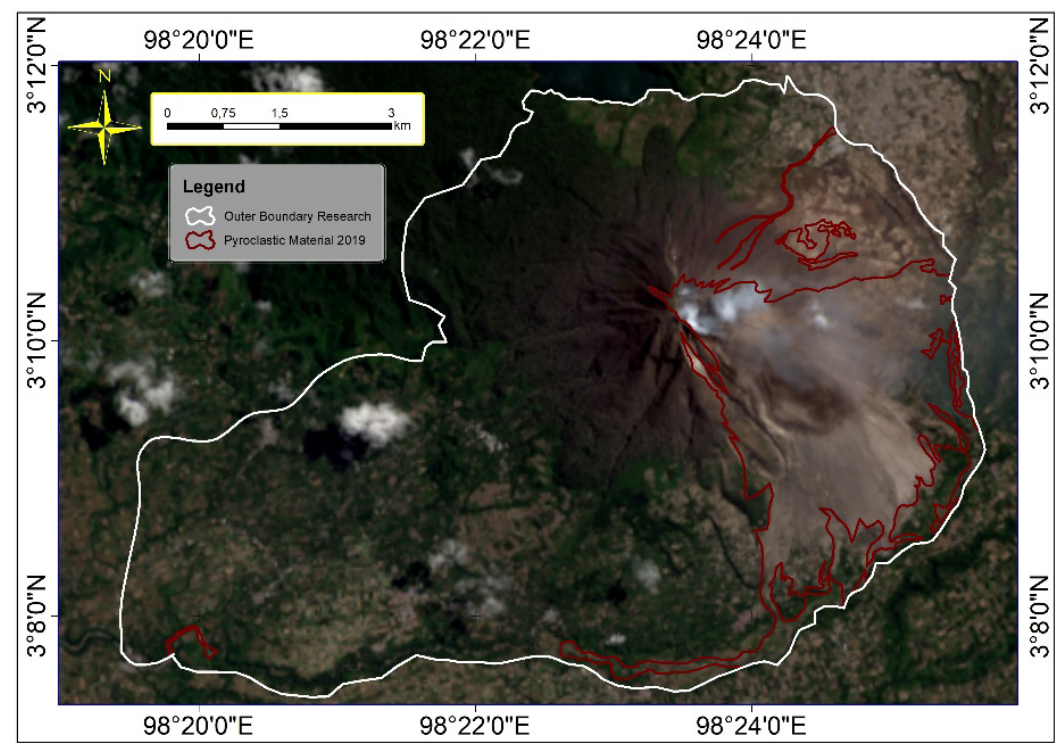

Figure 7. Landsat 8 (OLI) Satellite Imagery 2019.

After two mo0nths, Sinabung erupted again in November. This eruption was the most massive one since the beginning of activity in 2010. The height of the volcanic ash column in this month reached $8000 \mathrm{~m}$. In early 2014, Sinabung erupted once again, with the height of the volcanic ash column at around $4000 \mathrm{~m}$ (Figure 5). In August 2017, the height of the volcanic ash column reached $4200 \mathrm{~m}$, while in December 2017 it reached $4600 \mathrm{~m}$ (Figure 6).
In February 2019, it was recorded that Sinabung ejected volcanic ash as high as $5000 \mathrm{~m}$. From the Landsat imagery data, a difference in appearance can be seen between the pyroclastic deposits, forests, lakes and plantations (Kadavi et al., 2017). Therefore, Landsat imagery data were used as an object for Mount Sinabung pyroclastic material classification analysis (Figure 7).

This material significantly influences the surrounding land cover because of the eruptions (Figure 8). 




Figure 8. Map of Sinabung Volcano Land Covered by Pyroclastic Material in 2010-2019.

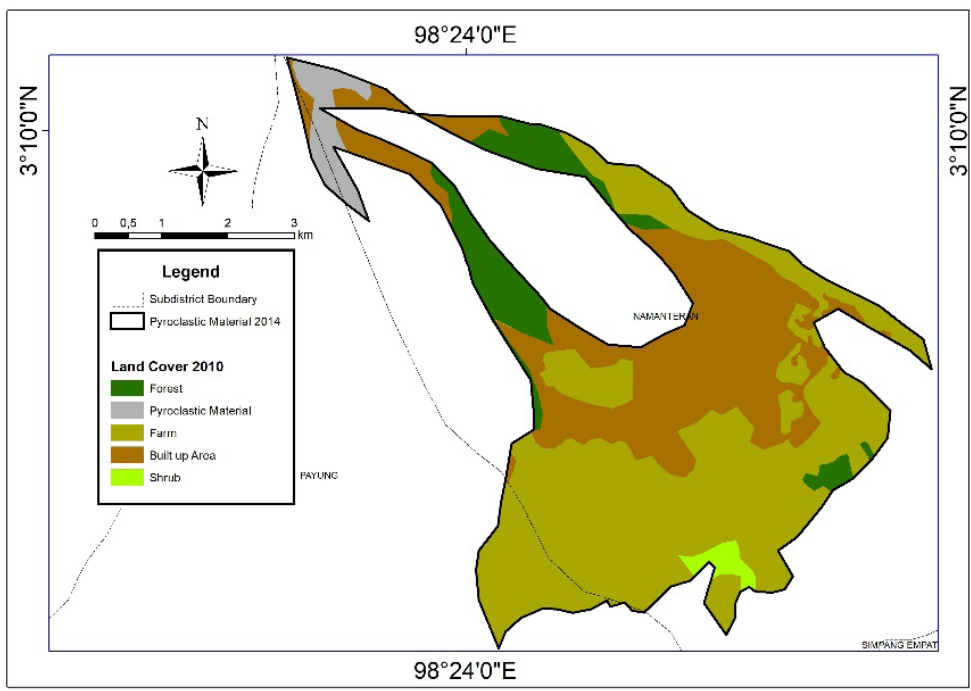

Figure 9. Map of 2010 Land Cover on 2014 Pyroclastic Material.



Figure 10. Map of 2010 Land Cover on 2014 and Pyroclastic Material in 2017. 
The pyroclastic material land cover expanded from 2010 to 2017. Conversely, postclassification comparisons examine changes over time between independently classified land cover data (Dewan and Yamaguchi, 2009; Yulianto et al., 2016). The total land cover changes due to pyroclastic material in 2010 was an area of $26.27 \mathrm{Ha}$; in 2014 it was $475.82 \mathrm{Ha}$, in $20171339.75 \mathrm{Ha}$; and in 2019 was $1196.11 \mathrm{Ha}$. The reason for the increasing pyroclastic material is the highly intensive series of eruptions of Mount Sinabung from 2017 to 2019. Although in 2019 the pyroclastic material land cover was lower than in 2017, this was due to the disappearance of such material around the Laborus Basin. The disappearance of the material in the Laborus watershed area is possibly due to the return of shrubs, because there is no cold lava flood in the Laborus watershed area. Directly, the pyroclastic material closes the land cover around the Mount Sinabung area. Indirectly, the impact produced is the large area of potential land abandoned due to the displaced population, as well as the impact of cold lava floods that can occur along the Laborus watershed. The eruptions of Mount Sinabung ejected considerable volcanic materials, one of which was pyroclastic flow (Kadavi et al., 2017). The pyroclastic flow deposits of Mount Sinabung spread to the southeast, tended to widen and were not transported far from the crater. These characteristics are the result of the acid-intermediate (andesitic-rhyolite) (Iguchi et al., 2011) magma of Mount Sinabung, which tends to be thick and prevents the pyroclastic flow deposit from being transported far. The reduction in land cover is also due to community mining activities, while the increase in cover is affected by the accumulation of cold lava floods (Clarisse et al., 2010).
During the eruption of 2010, there were yet to be many significant land changes. These began after the explosion of 2013, land changes as seen in Figure 9. The map shows the outer boundaries, which were pyroclastic materials in 2014, and the land cover represents that of 2010.

Eruptions from the end of 2013 until the beginning of 2014 began to show a wider distribution of pyroclastic material (Kadavi et al., 2017). The direction of the distribution of this material spread southeast from the summit of Mount Sinabung (Figure 10).

\section{Conclusion}

Land cover around the Sinabung volcano area experienced significant changes since the beginning of the eruptions in 2010 until the start of 2019. The large volume of pyroclastic material ejected was one of the causes of land cover changes. In the results of the interpretation of images by researchers, the direction of the Sinabung pyroclastic material tended to head southeast of the peak of the mountain. The use of Landsat imagery with a resolution of 30 meters at least produce a more in-depth analysis in monitoring the direction, pattern and movement of the Sinabung pyroclastic material. The total land cover changes due to pyroclastic material in 2010 was an area of 26.27 Ha; in 2014 it was $475.82 \mathrm{Ha}$; in 20171339.75 Ha; and in $20191196.11 \mathrm{Ha}$.

\section{Acknowledgements}

The author wishes to thank the Ministry of Research, Technology and Higher Education of The Republic of Indonesia for providing funding, and the communities near Sinabung volcano, Karo District, North Sumatra for the data and the opportunities given.

\section{References}

Amici, S., Turci, M., Giulietti, F., Giammanco, S., Buongiorno, M. F., Spina, A. La, ... Salinelle, L. (2013). Volcanic Environments Monitoring By Drones Mud Volcano Case Study. Int. Arch. Photogramm. Remote Sens. Spat. Inf. Sci, XL, 5-10.

Bachri, S., Irawan, L. Y., Wirawan, R., Nurjanah, A. E., Tyas, L. W. N., Utaya, S., \& Sumarmi. (2019). Dynamics of Lahar Material Deposition Post 2014 Kelud Eruption of Bladak River. 
IOP Conference Series: Earth and Environmental Science, 256(1). https:/ / doi.org/10.1088/1755$1315 / 256 / 1 / 012021$

Center of Volcanology and Geologic Disaster Mitigation (CVGDM) of. (2015). Disaster prone area of Sinabung Volcano.

Clarisse, L., Prata, F., Lacour, J. L., Hurtmans, D., Clerbaux, C., \& Coheur, P. F. (2010). A correlation method for volcanic ash detection using hyperspectral infrared measurements. Geophysical Research Letters, 37(19), 1-5. https://doi.org/10.1029/2010GL044828

Dewan, A. M., \& Yamaguchi, Y. (2009). Land use and land cover change in Greater Dhaka, Bangladesh: Using remote sensing to promote sustainable urbanization. Applied Geography, 29(3), 390-401. https:// doi.org/10.1016/j.apgeog.2008.12.005

Geologic Agency of Indonesia. (2011). Geologic Map of Sinabung Volcano.

Hartono, H. G., Sudradjat, A., \& Verdiansyah, O. (2017). Caldera of Godean, Sleman , Yogyakarta: A Volcanic Geomorphology Review, 31(July), 138-147. https://doi.org/10.23917/ forgeo.v31i1.2821

Hendrasto, M., Surono, Budianto, A., Kristianto, Triastuty, H., Haerani, N., ... Yoshimoto, M. (2012). Evaluation of Volcanic Activity at Sinabung Volcano , After More Than 400 Years of Quiet. J. Disaster Res., 7(1), 37-47. https:/ / doi.org/10.20965/jdr.2012.p0037

Iguchi, M., Ishihara, K., Surono, \& Hendrasto, M. (2011). Learn from 2010 Eruptions at Merapi and Sinabung Volcanoes in Indonesia, (54).

Kadavi, P. R., Lee, W., \& Lee, C. (2017). applied sciences Analysis of the Pyroclastic Flow Deposits of Mount Sinabung and Merapi Using Landsat Imagery and the Artificial Neural Networks Approach. https://doi.org/10.3390/app7090935

Kusumayudha, S.B. (2013). Active Volcanoes of Indonesia: 2nd ed. PT Citra Aji Parama: 2-21; 23.

Kusumayudha, S. B., Lestari, P., \& Paripurno, E. T. (2018). Eruption Characteristic of the Sleeping Volcano , Sinabung, North Sumatera , Indonesia , and SMS gateway for Disaster Early Warning System, 50(1).

Lee, C., Lu, Z., Kim, J., \& Lee, S. (2015). Volcanic activity analysis of Mt . Sinabung in Indonesia using Remote Sensing and GIS techniques Seogwipo-si , Jeju-do , 697-845 , Republic of Korea ( 2 ) Roy M. Huffington Department of Earth Sciences, Southern Methodist University , USA, (1), 2013-2016.

Ministry of Energy and Natural Resources of the Republic of Indonesia. (2013). 1.4. sinabung, sumatera utara.

Primulyana, S., Kern, C., Lerner, A. H., Saing, U. B., Kunrat, S. L., Alfianti, H., \& Marlia, M. (2018). Gas and ash emissions associated with the 2010-present activity of Sinabung Volcano, Indonesia. Journal of Volcanology and Geothermal Research. https://doi.org/10.1016/j.jvolgeores.2017.11.018

Raynolds, M., Magnússon, B., Metúsalemsson, S., \& Magnússon, S. H. (2015). Warming, Sheep and Volcanoes: Land Cover Changes in Iceland Evident in Satellite NDVI Trends, 94929506. https://doi.org/10.3390/rs70809492

Sadidy, J., Firouzabadi, P. Z., \& Entezari, A. (1981). The Use of Radarsat and Landsat Image Fusion Algorithms and Different Supervised Classification Methods To Improve Landuse Map AccuracyCase Study: Sari Plain-Iran. Department of Geography, Taebiat Moallem Sabzevar University. 
Setiawan, C. (2019). Zoning of School Vulnerability to Sinabung Eruptions in Karo District, North Sumatra Province , Indonesia. https:// doi.org/10.1088/1755-1315/271/1/012018

Setiawan, Cahyadi, Suratman, S., \& Marfai, M. A. (2017). The Relationship between Total Income and Groundwater Utilization on Fluviomarine Landform Area in Jakarta. Forum Geografi, 31(1), 69. https://doi.org/10.23917/forgeo.v31i1.2851

Somantri, L. (2008). Pemanfaatan Citra Penginderaan Jauh Untuk Mengidentifikasi Patahan Lembang. Fakultas Pendidikan Ilmu Pengetahuan Sosial UPI, 1-11.

Supartoyo, Surono, \& Putranto, E. T. (2014). Katalog Gempabumi Merusak Di Indonesia Tahun 1612-2014, 2014(57), 134.

Wardhani, P. I., \& Sartohadi, J. (2017). Dynamic Land Resources Management at the Mount Kelud , Indonesia, 31(July), 56-68. https://doi.org/10.23917/forgeo.v31i1.3612

Wright, H. M. N., Pallister, J. S., McCausland, W. A., Griswold, J. P., Andreastuti, S., Budianto, A., ... Gunawan, H. (2018). Construction of probabilistic event trees for eruption forecasting at Sinabung volcano, Indonesia 2013-14. Journal of Volcanology and Geothermal Research, (2017). https://doi.org/10.1016/j.jvolgeores.2018.02.003

Yulianto, F., \& Sofan, P. (2016). The Utilization of Remotely Sensed Data to Analyze the Estimated Volume of Pyroclastic Deposits and Morphological Changes Caused by the 2010-2015 Eruption of Sinabung Volcano, North Sumatra, Indonesia. Pure and Applied Geophysics, 173(8), 2711-2725. https:/ / doi.org/10.1007/s00024-016-1342-8

Yusnikusumah, T. R., \& Sulistyawati, E. (2016). Evaluasi Pengelolaan Ekowisata di Kawasan Ekowisata Tangkahan Taman Nasional Gunung Leuser Sumatera Utara. Jurnal Perencanaan Wilayah Dan Kota, 27(3), 173. https:/ / doi.org/10.5614/jrcp.2016.27.3.1 